\title{
Tree Growth and Climate Relationship: Dynamics of Scots Pine (Pinus Sylvestris L.) Growing in the Near-Source Region of the Combined Heat and Power Plant During the Development of the Pro-Ecological Strategy in Poland
}

\author{
Barbara Sensula • Sławomir Wilczyński • \\ Magdalena Opala \\ Received: 24 February 2015 / Accepted: 2 June 2015 /Published online: 22 June 2015 \\ (C) The Author(s) 2015. This article is published with open access at Springerlink.com
}

\begin{abstract}
Since the 1990s, the emission of pollutants was reduced in a majority of Polish and developing country factories whereas the level of energy production was similar to that prior to the 1990s. The conifer investigated in this study has grown for many years under the stress of industrial pollution. Despite this, the trees are preserved, to a large extent, sensitive to the natural climatic factors. We present a complex analysis of the climatic (sunshine, temperature, precipitation, humidity, and wind circulation) and anthropogenic factors influencing the radial increment dynamics of Scots pine (Pinus sylvestris L.) growing in the vicinity of the combined heat and power station in Laziska (Poland). We analyzed the spatiotemporal distribution of growth reductions, the depth of reduction with respect
\end{abstract}

\footnotetext{
B. Sensuła $(\bowtie)$

Institute of Physics-Center for Science and Education,

Silesian University of Technology, Konarskiego 22B,

44-100 Gliwice, Poland

e-mail: Barbara.sensula@polsl.pl

S. Wilczyński

Institute of Forest Ecosystem Protection, Department of Forest Protection, Entomology and Forest Climatology, University of Agriculture in Krakow, Al. 29 Listopada 46, 31-425 Kraków, Poland

e-mail: rlwilczy@cyf-kr.edu.pl

\section{Opała}

Department of Climatology Faculty of Earth Sciences, University of Silesia, Bedzinska 60, 21-200 Sosnowiec, Poland

e-mail: magdalena.opala@us.edu.pl
}

to the distance from the emitter, the relationship between tree growth and climate during the industry development period and during proecological strategy application. Samples of carbon isotopic composition in pine needles from 2012 to 2013 were additionally determined. Pines series of 3 positions indicate that they have a similar sensitivity to most climatic elements of the previous and given year, but there is also a different rhythm between the studied populations of incremental growth of pines. The causes of diversity are due to the different types of habitat (site types) and industrial pollution. The variation in carbon stable isotopic composition in pine needles was connected with an increase of $\mathrm{CO}_{2}$.

Keywords Pine - Climate changes · Pollution · Tree growth $\cdot$ Combined heat and power station $\cdot$ Carbon isotopes in needles

\section{Introduction}

Trees are a very good archive of ecosystem change in which they are grown. Trees are sensitive to climate changes and anthropogenic pollution. The changes in the ecosystem can disturb the metabolism and physiological processes of trees, and consequently, they also have an effect on the wood structure (Schweingruber 1996; De Vries et al. 2000). Climatic and anthropogenic signals can be recorded in tree ring width (TRW) and the isotopic composition of wood and its components 
(Schweingruber 1996; De Vries et al. 2000; McCarroll et al. 2009; Sensuła et al. 2011; Sensuła and Pazdur 2013a, b ; Pazdur et al. 2007, 2013). The size of TRW reduction can be affected by the chemical composition of pollution and also depends on the distance from the pollution source (e.g., Wilczyński 2006; Elling et al. 2009). Therefore, the annual TRW reduction can be a source of information about the industrial history and changes in the quality of the natural environment (Cook and Innes 1989).

Tree rings are a useful tool in long-term biomonitoring that can provide annual records of ecosystem changes over several decades, even countries. The systematic long-term monitoring of air pollutants is generally limited to the last decadas and restricted to the point source (e.g., Szychowska-Krapiec and Wiśniowski 1996; Malik et al. 2012). Trees are an archive of historical changes in the environment. For years, dendrochronological monitoring has successfully been used in the studies of industrial development involving different types of industrial production, such as power stations (e.g., Levanič and Slapnik 2006). Abrupt changes in environmental conditions, such as an increase in air pollution, influence cambium activity and can be responsible for the occurrence of abrupt growth reductions or missing rings (Schweingruber 1986). Until the time that human activities began to alter the natural cycle of different elements carbon dioxide, nitrogen oxides, and sulfur oxides served as one of the major limiting factors that controlled the dynamics, biodiversity, and functioning of many ecosystems (Vitousek et al. 1997). Some of the pollutants are restricted to small, near source region whereas the others are distributed over much larger areas. Human alterations of the carbon, nitrogen, and sulfur cycle have accelerated losses of biological diversity, especially among sensitive plants, and subsequently, the animals and microbes that depend on these plants. It has also caused changes in the plant and animal life and ecological processes. Nitric oxide plays several critical roles in atmospheric chemistry, including catalyzing the formation of photochemical (or brown) smog. In the presence of sunlight, nitric oxide and oxygen react with hydrocarbons emitted by automobile exhausts to form ozone, the most dangerous component of smog. Ground-level ozone has serious detrimental effects on human health as well as the health and productivity of crops and forests. Nitric oxide, along with other oxides of nitrogen and sulfur, can be transformed in the atmosphere into nitric acid and sulfuric acid, which are the major components of acid rain (Vitousek et al. 1997).

The stable isotope ratios of the light elements (carbon, oxygen, and hydrogen) in the plant are very valuable tools in the investigating climate changes and anthropogenic effects connected with the development of industry. The observed anthropogenic impact of the global carbon cycle, mainly related to fossil fuel and biomass burning, land-use changes, and various industrial activities (O’Leary 1981; Leavitt and Long 1982) causes change in the isotopic composition of carbon not only in the atmosphere but also in the biosphere. Nevertheless, there is lack of short-term contemporary spatiotemporal analysis of the current fractionation of carbon isotopes within an industrial area, in near source region.

The investigated area is located near to combined heat and power plant "Laziska," which is the third in Silesia and the ninth largest power station in Poland and produces about $4.2 \%$ of the nation's electricity production. In 2000, the Łaziska Power Station became part of Polish Energy Company (PKE). Since 2011, it belongs to the Tauron Wytwarzanie SA. The power plant in Łaziska was founded in 1917. In the years 1927-1953, it was the largest power plant in Poland. According to the assumptions of the investor, the power plant was to be powered by coal of inferior quality, the large quantities of which were difficult to sell. In 1953, the power of Łaziska was 191.1 MW. Since 1960, electricity production has quadrupled. The next stage of expansion of the power plant included major investments in environmental protection: the creation of a sewage treatment plant, installation of electrostatic precipitators on new blocks, electricity produced exclusively on new blocks. In 1990, the Łaziska Power Station was one of the most oppressive environment. In 1990, the Laziska Power Station included provisions contained in the Decision Restorative Department of Environmental Protection, Water and Geology Provincial Office in Katowice. Since that time, boiler furnace systems for NOx reduction were modernized, and also, flue gas desulfurization plant was modernized. In fact, in 2000, the power station disappeared from the list of companies most burdensome for the environment, and today, this power plant is one of the best, the most environmentally friendly, and the most modern coal-fired power plant in Poland. Figure 2 shows the effect of the power plant modernization and the changes in level of pollutant emission, 
whereas the level of energy production is similar. Decreases in the high rate of air pollution in 1990s clearly reflect the successive stages of the modernization of the industrial plant; at the same time, it can be observed that the level of production at that time remains the same. Most of the modernization in different plants and the industrial sector in Eastern Europe is connected with access to EU funding in the past decades and EU legislation and the implementation of restrictive governmental regulations on emissions.

The investigated area is characterized by very significant transformation of the natural environment caused by mining and metallurgy, as well as the growth of Poland's largest urban-industrial agglomeration (Kondracki 2001). The relief of the Katowice Upland is one of the most transformed in Poland and Central Europe. Typical anthropogenic landforms, such as incisions, embankments, excavations, dumps, water reservoirs, and water flows, commonly occur (Szypuła 2014). Changes in the air quality (high amount of dust and gas pollutants within the entire area of the Katowice Region, contributing to the occurrence of "acid rains" phenomenon) were reported (Leśniok 2011Environmental pollution adversely affects the health of the population (Absalon and Ślesak 2010), quality of life (Absalon and Ślesak 2012), as well as the condition of forests (Breymeyer 1998) and soil properties (Heller et al. 1998). The predominant types of soils in this area are Albic Luvisol. Haplic Podzols are present in the flat depressions and Haplic Fluviosols in the valley bottoms. Technic Regosols and different soil units of contaminated soils are typical for the urban-industrial areas (Lazar 1962). Potential natural vegetation is composed of mixed oak-pine forests (Querco-Pinetum) and oak-hornbeam forests (Tilio-Carpinetum) (Matuszkiewicz 2008). At present, acidophilus oak forests (Quercetea roboripetraeae) are fragmentarily preserved, although the artificial planting of pine predominates. This area is characterized by the highest level of industrialization in Poland (Figs. 1 and 2, Marland et al. 2008), where the highest values of dust and gaseous pollutants were recorded in late 1970s. It should be mentioned that other emitters from the southern part of Poland and from Germany and Tcheck Republic could influence not only the atmosphere but also the biosphere and trees.

The aim of the presented study is the analysis of the factors influencing the radial increment dynamics of Scots pine (Pinus sylvestris L.) growing in the vicinity of the Combined Heat and Power station (CHP) in
Laziska (Poland). The specific objective of this study was the determination of CHP air pollution effects on the following: (1) the spatiotemporal distribution of growth reductions, (2) the depth of reduction with respect to distance from the emitter, (3) relationship between radial growth of pines and climate during the period of development of industry, and (4) the spatiotemporal fractionation of carbon stable isotopes in the needles of pine collected in 2 consecutive years (2012 and 2013).

\section{Materials and Methods}

The sampling sites are exposed to typical anthropogenic stress of heavily urbanized areas in close to proximity of the large power station in Łaziska. The highest part of the study area reaches about $350 \mathrm{~m}$ a.s.l. at Mikołów Horst, but the elevation near the research sites goes down to 260-290 $\mathrm{m}$ a.s.1. Three sampling sites located in ENE direction from the emitter were selected (Fig. 3a, b) in accordance with the direction of the prevailing wind (Fig. 3c), at distances from 3 to $12 \mathrm{~km}$ from the plant (Table 1). The scale of impacts of regional and local types of pollution can be dependent on the meteorological and circulation conditions. The circulation type can significantly influence the pollution level and favor the concentration or dispersion of air pollution (Niedźwiedź and Ustrnul 1989). Among all synoptic situations, the highest pollution levels (dust, $\mathrm{SO}_{2}$, $\mathrm{NO}_{2}$, and $\mathrm{O}_{3}$ ) occurred during anticyclonic circulations, with an advection of air masses from the south and southwest (Sa and SWa) (Leśniok et al. 2010).

Despite the high building density, uneven distribution of forests, and their high species and age differentiation, sites with similar habitat conditions and age structure have been selected. Scots pine (P. sylvestris L.) at an age of about 100 years predominated at all the research sites. Due to the species composition of the forest in the study area, Scots pines were selected for investigations. This common species is considered to be sensitive to the anthropogenic effect (Schweingruber 1996; De Vries et al. 2000; Sensuła et al. 2011; Sensuła and Pazdur 2013a, b; Pazdur et al. 2007, 2013). In order to avoid a different dendroecological reaction of juvenile wood, an attempt was made to select pine stands aged between 90 and 100 years (felling age of Scots pine). In summer 2012, cores of the dominant trees were taken with Pressler's borer at the breast 
Fig. 1 National level of carbon emissions from different sources from the 1850-2012 period. The emission of carbon is expressed in million metric ton of carbon

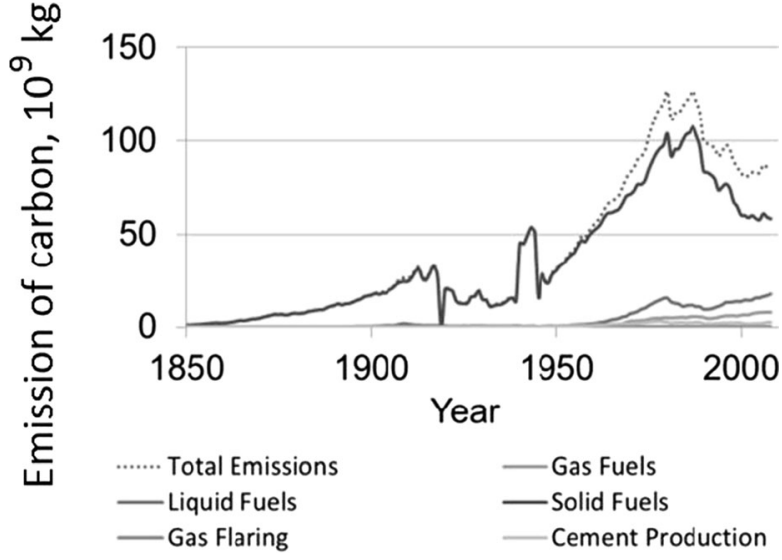

calculated between all pairs of indexed series drawn from different pines. Rbt is commonly used to represent the chronology signal (Briffa and Jones 1992). The EPS is a statistic for examining the common variability in a chronology, and it is dependent upon the sample depth, whereas the SNR informs about the ratio between the signal (short-term variation) and the noises (long-term variation) contained in chronologies of the investigated trees (Wigley et al. 1984).

A value of 0.85 , usually cited as an acceptable threshold, was also used here (Wigley et al. 1984; Speer 2010). Climate data (monthly air temperature, total precipitation, humidity, sunshine, and wind directions) from the nearest meteorological station located in Katowice (Fig. 4). The meteorological data covered the period of time since 1951-2012 were obtained thanks to the Polish Institute of Meteorology and Water Management (IMGW-PIB).

During the 1951-2012 period, the investigated area was characterized by a mean annual temperature ca. $8^{\circ} \mathrm{C}$, the mean total annual precipitation equal to ca. $720 \mathrm{~mm} /$ year, sunshine equal to ca. $1530 \mathrm{~h} /$ year, and relative humidity equal to ca. $78 \%$. The study area was dominated by winds from the southwest and the west (Fig. $3 \mathrm{c}$ ). The mean annual temperature and sunshine increased, whereas humidity decreased during the last decades. The highest temperature, sunshine, and precipitation were noted between May and August. A significant variation of climatic factors has influenced tree growth and the dynamics of tree ring radial growth. Climatic factors affecting the radial growth variability were determined by the correlation and response functions (Fritts et al. 1971; Fritts 1976). The correlation and response coefficients between site residual chronologies 


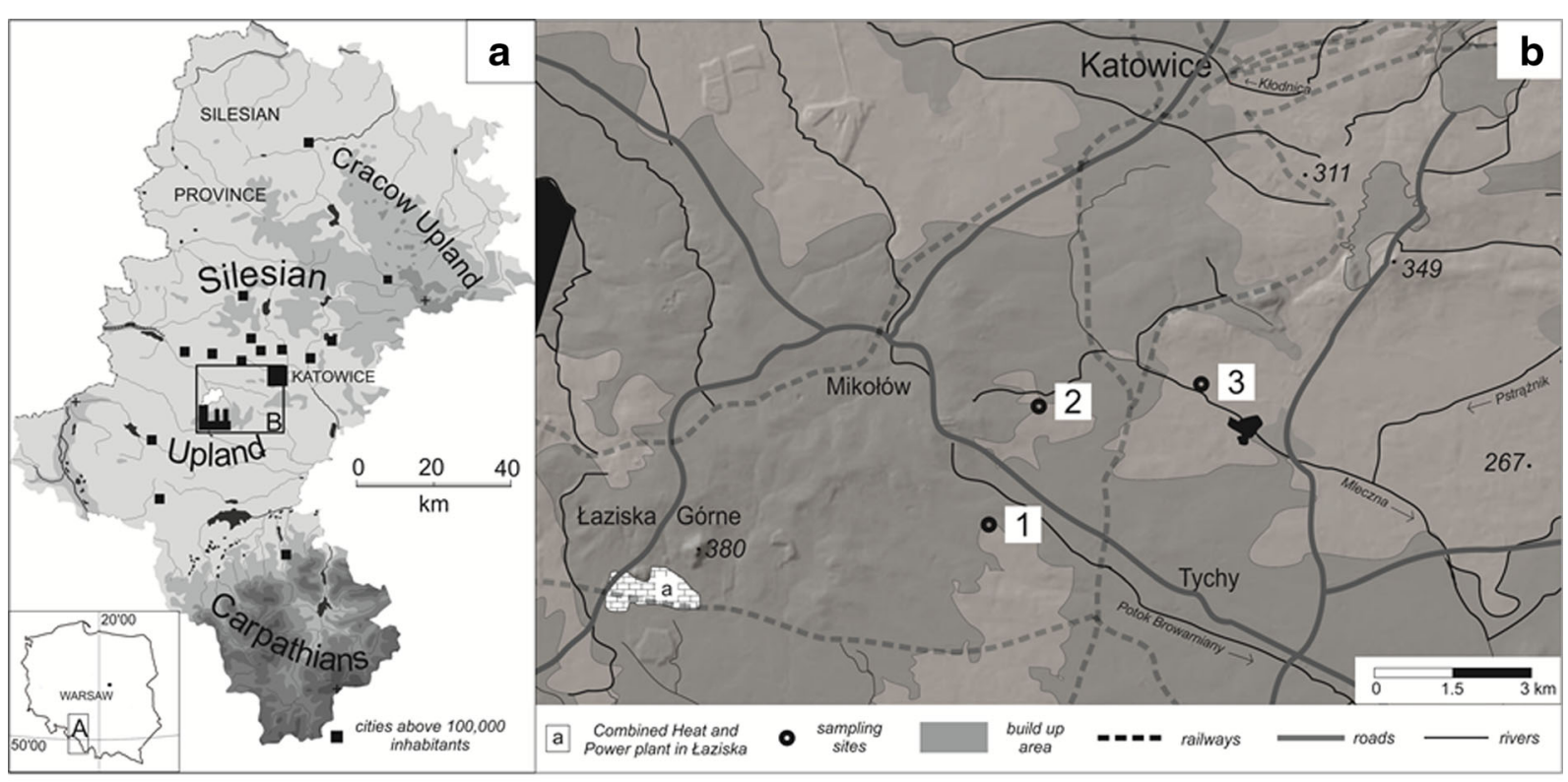

c

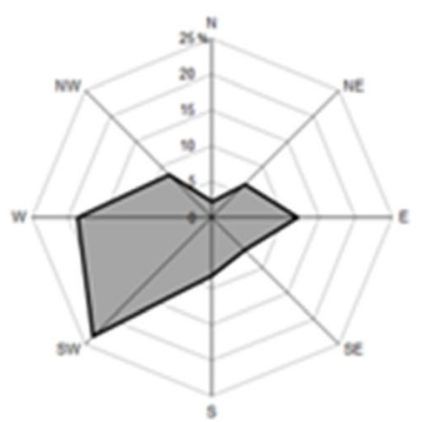

d
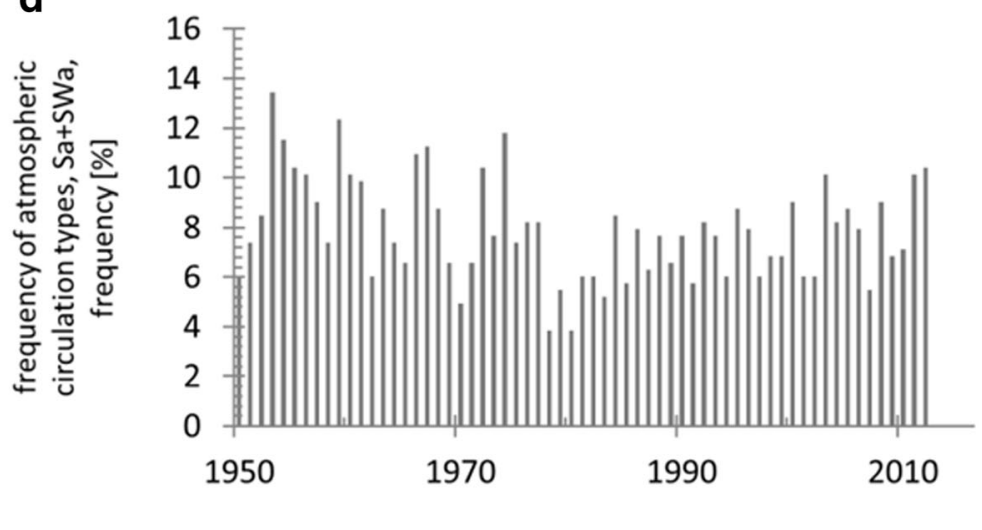

Fig. 3 Investigated site: a location of the study area in the Silesian Province; $\mathbf{b}$ detailed location of the sampling sites (1-3) in the vicinity of the Combined Heat and Power Plant in Łaziska; $\mathbf{c}$ distribution of wind directions; and $\mathbf{d}$ dominant circulation types

and monthly climatic data were calculated by the RESPO computer software (Holmes and Lough 1999) and then compared with the results from Dencdroclim2000 (Biondi and Waikul 2004). This program uses 1000 bootstrapped samples to compute the correlation and response coefficients and to test their significance at the 0.05 level. The dependent variables were the indices of site residual chronology from 1951 to $2012(n=62)$. The independent variables were the monthly values of a maximum and minimum

Table 1 Main characteristics of the sampling sites: time span, number of cores collected, and localization of sampling site

\begin{tabular}{|c|c|c|c|c|c|c|}
\hline $\begin{array}{l}\text { Research } \\
\text { site }\end{array}$ & $\begin{array}{l}\text { Lab } \\
\text { code }\end{array}$ & $\begin{array}{l}\text { Time span } \\
\text { (years) }\end{array}$ & $\begin{array}{l}\text { No of } \\
\text { cores }\end{array}$ & $\begin{array}{l}\text { Distance from } \\
\text { pollution source }[\mathrm{km}]\end{array}$ & $\begin{array}{l}\text { Geographical } \\
\text { coordinates }\end{array}$ & $\begin{array}{l}\text { Elevation } \\
{[\mathrm{m} \text { a.s.1.] }}\end{array}$ \\
\hline 1 & LW & $1922-2012(91)$ & 20 & 3 & $50^{\circ} 08^{\prime} \mathrm{N}, 18^{\circ} 56^{\prime} \mathrm{E}$ & 280 \\
\hline 2 & LM & $1914-2012$ (99) & 20 & 7 & $50^{\circ} 09^{\prime} \mathrm{N}, 18^{\circ} 57^{\prime} \mathrm{E}$ & 290 \\
\hline 3 & LP & $1917-2012(96)$ & 20 & 12 & $50^{\circ} 10^{\prime} \mathrm{N}, 18^{\circ} 59^{\prime} \mathrm{E}$ & 260 \\
\hline
\end{tabular}


Fig. 4 Climatic conditions in investigated areas from 1951 to 2012: (temperature: monthly minimum and maximum, mean annual; precipitation: monthly and annual sum, sunshine monthly and annual sum of number of hours, humidity monthly and annual mean) for the Katowice meteorological station from 1951 to 2012
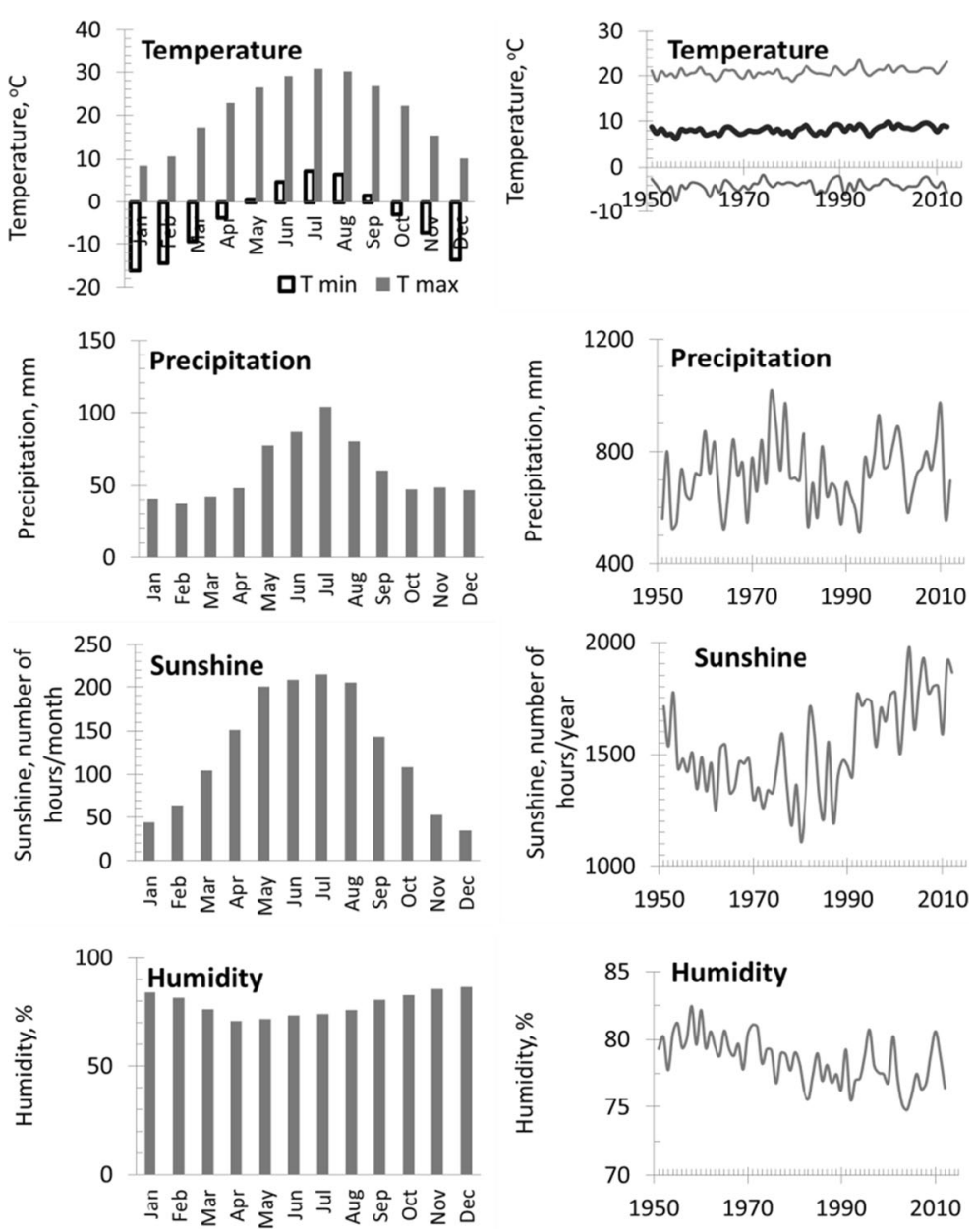

temperature, total precipitation, total sunshine duration, and relative humidity from August of the year previous to September of the current year of the ring formation $(n=14)$. A principal component analysis (PCA) was applied to describe the relationships between the radial increment of pines and climate parameters and to identify the factors affecting TRW. PCA was used to reduce the residual series of 60 trees to orthogonal principal components. Based on a screen plot, two first principal components were used. The identification of PC1 and PC2 was based on an analysis of the component scores. For this purpose, the correlation and response function were again used. The dependent variables were the scores of PC1 and PC2.

Air pollution emissions were not continually monitored in the investigated area, and most of the data is only available for the last 20 years. We used the following database of pollution: $\mathrm{CO}_{2}$ emission in Poland since 1950 - Carbon Dioxide Information Analysis Center
(Marland et al. 2008); $\mathrm{CO}, \mathrm{SO}_{2}, \mathrm{NO}_{\mathrm{x}}$, and dust emission in the Silesian Province since 1975-Statistical Yearbooks of the Environmental Protection 19752012, Reports of Environment Protection Bureau in Huta Katowice (B.O.Ś 2002, 2006); $\mathrm{SO}_{2}, \mathrm{NOx}$, and dust emission from Combined Heat and Power Plant in Laziska-Environmental Statement of Laziska Power Station 2009, 2012). Due to the administrative changes in Poland in 1999, data for the Province for the years 1975-1999 was calculated as a sum of values for three former provinces: Bielsko, Katowice, and Czestochowa Province and data for current Silesian Province was used for the years 2000-2012. The correlation between local air pollution emission on TRW was made with using Statistica softwere (Statistica 10.0 software).

An additional dendro-ecological analysis was carried out according to the method used by Schweingruber (1986), in which the reduction values are calculated as 
the total TRW in the reduction period in relation to the same number of rings from the period preceding the reduction. The calculated reductions were classified as follows: moderate reductions, $30-50 \%$; strong reductions, $51-70 \%$; and very strong reductions, $>70 \%$.

Additionally, the samples of pine needles from each site were collected in 2012 and 2013. The samples were washed in distilled water and then dried and homogenized and shredded. The measurement of carbon isotopes was carried out in the Mass Spectrometry Laboratory (Department of Radioisotopes, Institute of Physics, Gliwice, Poland), using the isotope ratio mass spectrometer (IsoPrime) coupled to the Eurovector elemental analyzer at a combustion temperature of $1020^{\circ} \mathrm{C}$ (GV Instruments, Manchester, UK). The precision on triplicates was $\pm 0.26 \%$ o $(n=50)$. The relative deviation of the isotopic composition is expressed in parts per thousand (\%), as follows:

$\delta=\left(\frac{R_{\text {sample }}}{R_{\text {standard }}}-1\right) \cdot 1000$

where $\mathrm{R}_{\text {sample }}$ and $\mathrm{R}_{\text {standard }}$ are the ratios of the heavy to the light isotope concentration in the sample and in the standard, respectively. The reference standard for carbon is the isotopic ratio in the Vienna Peedee Belemnite (VPDB).

\section{Results}

The series of TRW and normalized indices (RWI) were created for each tree (Fig. 5). The statistical characteristics of the site residual series and chronologies for the period 1951-2012 are presented in Table 2. The pines of each population are characterized by a high similarity of short-term increment reactions $\left(\mathrm{r}_{\mathrm{bt}}\right.$ indices ranged from 0.399 to 0.514 ) (Table 2). The site residual chronologies are characterized by a high representativeness (indices EPS ranged from 0.930 to 0.954 ). The percentage of the variance of 60 residual series explained by $\mathrm{PC} 1$ is $43.4 \%$ and that by $\mathrm{PC} 2$ is $6.7 \%$ (Fig. 6). PC1 is the most effective for the description of the variations in the radial increment. The location of the residual series with regard to the loadings indicates that $\mathrm{PC} 1$ integrates the series. The residual series correlate positively with $\mathrm{PC} 1$ $(P<0.01)$ (Fig. 6). The PC2 differentiates the series into two groups. The first group is constituted by a series of LW and LP populations. They correlate positively with

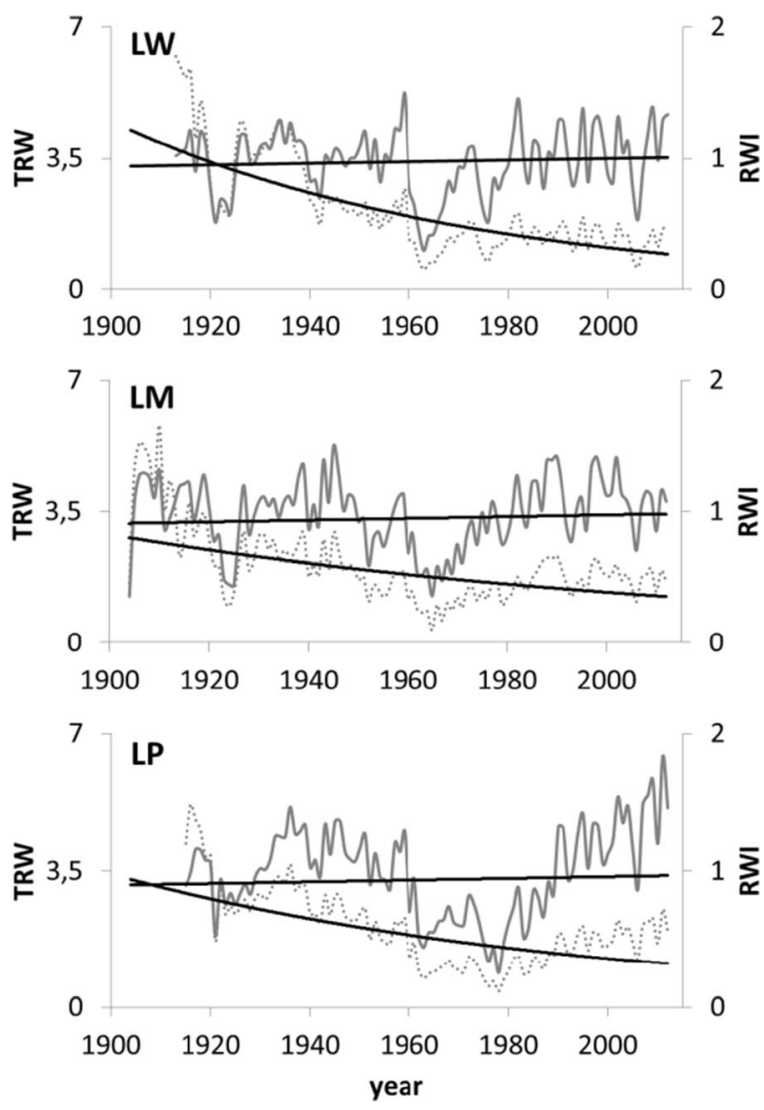

Fig. 5 Annual increment growth of Scots pines from the investigated sites and the negative exponential fit lines (solid lines RWI, pointed lines TRW)

PC2. The series of the LM population correlate negatively with PC2 (Fig. 6). This division of series is related to the site habitat. As a result, $\mathrm{PC} 1$ can be described as a multisite radial increment index. This has a similar effect on the short-term radial increment in all the pine populations. The second principal component can be described as a specific parameter for a tree stand site. PC2 describes factors to which the pines of each population show different sensitivity. The size of the radial increment shows a statistically significant relationship to the maximum temperature of September of the year preceding the radial increment and a maximum temperature in February, March, and May of the current year. The variation of the radial increment is influenced by the September minimum temperature of the previous year and the minimum temperature of February and March of the current year. It is determined that PC1 show a significant relationship to the total hours of sunshine during September of the previous year and May of the year of the ring formation (Fig. 7). Moreover, it is 
Table 2 Statistical characteristics of the site residual series and chronologies for the 1951-2012 period: number of series investigated, mean tree ring width (TRW), mean tree ring indices (TRI), mean sensitivity, between-tree signal $\left(\mathrm{r}_{\mathrm{bt}}\right)$, expressed population signal (EPS), signal to noise ratio (SNR)

\begin{tabular}{|c|c|c|c|c|c|c|c|c|}
\hline Lab code & No of series & Mean TRW (mm) & Mean TRI & Mean sensitivity & Correlation with master chronology & $\mathrm{R}_{\mathrm{bt}}$ & EPS & SNR \\
\hline LW & 20 & 1.95 & 0.97 & 0.284 & 0.578 & 0.508 & 0.953 & 20.6 \\
\hline LM & 20 & 2.07 & 0.99 & 0.308 & 0.520 & 0.514 & 0.954 & 21.1 \\
\hline LP & 20 & 1.98 & 1.00 & 0.285 & 0.591 & 0.399 & 0.930 & 13.3 \\
\hline
\end{tabular}

significantly correlated with the total precipitation of the previous September and May, and July of the current year. The PC1 also show a significant relationship to the mean relative humidity of the previous September and the current April and May (Fig. 7). The PC2 indicate a significant relationship to the minimum temperature of February, May, June, and July in the year of the tree ring formation (Fig. 7). The analyses of the correlation and response functions undertaken for 3 site chronologies confirm the above results (Fig. 8). All the elements included in the analysis of climate variability affect the dynamics of radial growth. This is evidenced by the high values of the coefficients of determination. Comparing two different softwares-RESPO and Dendroclim2000 - it is evident that both software solutions gave similar selected statistics results at the $95 \%$

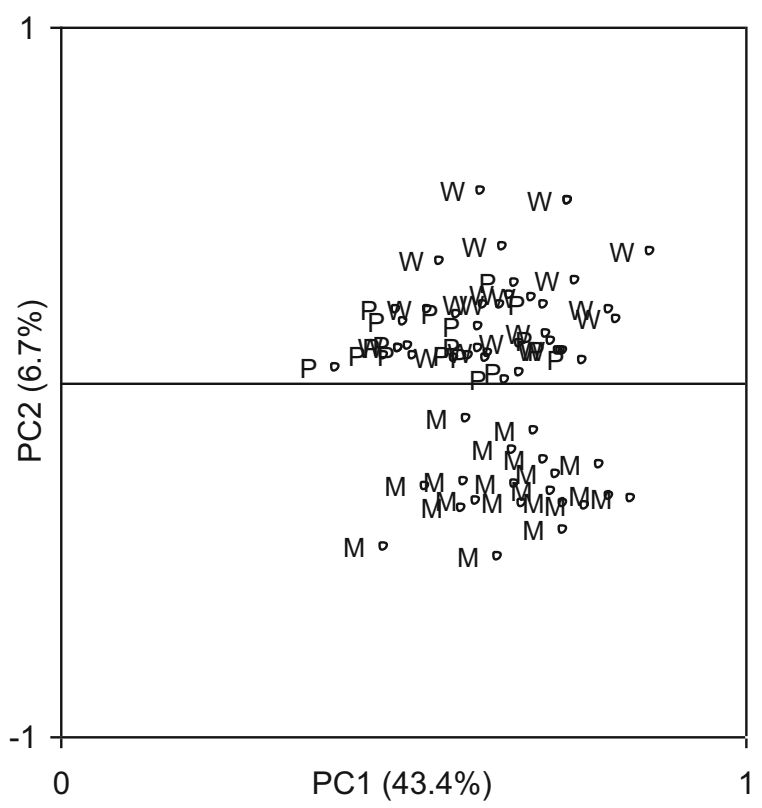

Fig. 6 The location of the residual series in relation to the component loadings of $\mathrm{PC} 1$ and $\mathrm{PC} 2$. The brackets contain the variance of the chronologies explained by PC1 and PC2. $M$ population LM, $W$ population LW, and $P$ population LP confidence limit. In figures, we presented the RESPO results.

The analysis of the influence of local air pollution emission on TRW confirmed the regional (national) negative effect of the increase of $\mathrm{CO}_{2}$ emissions from fossil fuel combustion (Figs. 9 and 10), the negative effect of increase of the local (Silesian, Fig. 11) air pollution emissions $\left(\mathrm{CO}, \mathrm{SO}_{2}, \mathrm{NO}_{\mathrm{x}}\right.$, dusts) and also the local negative effect of the distribution of air pollution such as NOx, SOx, and dusts from sources near the investigated site - the Combined Heat and Power Plant in Łaziska (Fig. 12). The signal strength is variable and depends on the distance from the source. The reduction of gaseous and dusts emission is also recorded in the TRW.

The spaciotemporal analysis of industrial air pollution, such as sulfur dioxide, nitrogen oxides, and dust, emitted from the Łaziska Power Station shows a significant linear correlation between the emission of $\mathrm{NO}_{\mathrm{x}}$ pollution and TRW between 1989 and 2000 only in one sampling site (LM) located at a distance of $7 \mathrm{~km}$ from this near source of pollution $(r=-0.68, p<0.02)$. Higher emissions of NOx reduced TRW. Due to the lack of data, it is impossible to compare the pollution level before 1989 and TRW reduction. Between 1990 and 2000 , this power station was placed on the list of the most oppressive for environment. Since 2000, there has been significant linear correlations between dusts and $\mathrm{NO}_{\mathrm{x}}$ emitted from the Laziska Power Station and TRW observed for the sampling site located at a distance of $3 \mathrm{~km}\left(r=-0.55\right.$ for $\mathrm{NO}_{\mathrm{x}}$ and $r=-0.53$ for dust emission, $p<0.1$, respectively) and at a distance of $12 \mathrm{~km}$ from the power station $(r=-0.51$, for dust emission, $p<0.1)$. Increase of $\mathrm{SO}_{2}$ emission corresponds to narrow rings, and a decrease of $\mathrm{SO}_{2}$ emission corresponds to the increase in TRW.

We have also noted differences in carbon stable isotope fractionation in pine needles (Fig. 9), which were similar for the LP and LW, but different in the LM. 


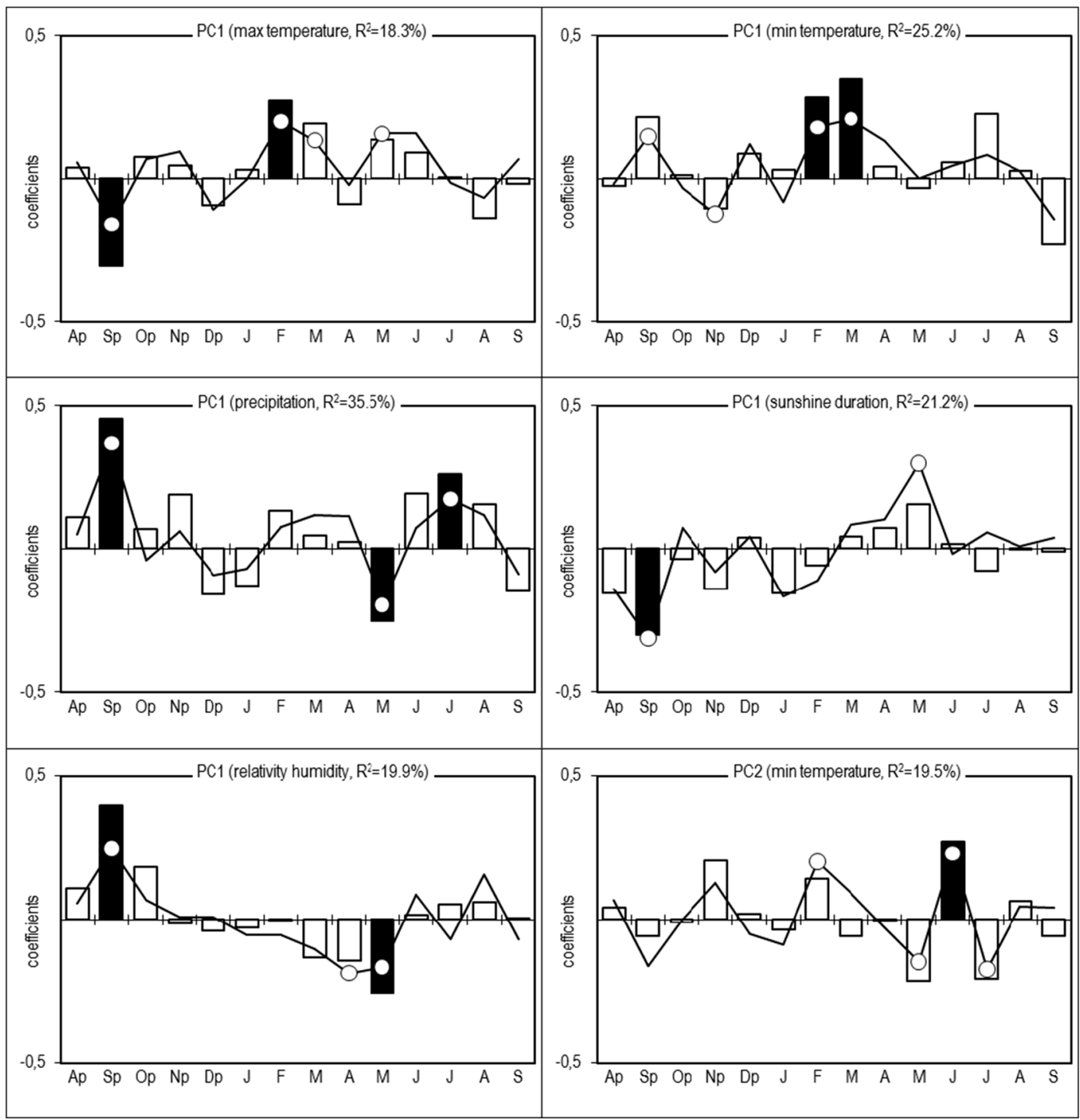

Fig. 7 Correlation (bars) and response function (lines) coefficients between the scores of PC1 and PC2, and the monthly maximum and minimum temperatures, total precipitation and sunshine duration, and relative humidity for all months from the

previous August (Ap) to the current September (S) from 1951 to 2012. Significant values (at the $95 \%$ confidence limit) - black bars and white dots, $R^{2}$ - the coefficient of multiple determination

\section{Discussion}

The three tree ring chronologies built in this study create the local pattern of each pine population undertaken in this study. These patterns are the archive of the pine incremental response to various environmental factors. A strong positive correlation with the first principal component of pines series from 3 sampling sites indicates that they have a similar sensitivity to most climatic elements described by $\mathrm{PC} 1$. A scatter of results of test batches in relation to $\mathrm{PC} 2$ indicates, however, that there

are also different rhythms between the studied populations of incremental pines. Therefore, climate-growth relationships estimated for the LM population should not be generalized to other populations. The cause of the diversity of these compounds may be the impact on tree industrial pollution (Wilczyński 2006). LM population pines showed smaller radial growth reductions, as compared to others. It seems that in this case, a type of habitat (site type) where tree has been growing is significant. The other two populations have been growing in the poorer habitats of a mixed coniferous forest site 


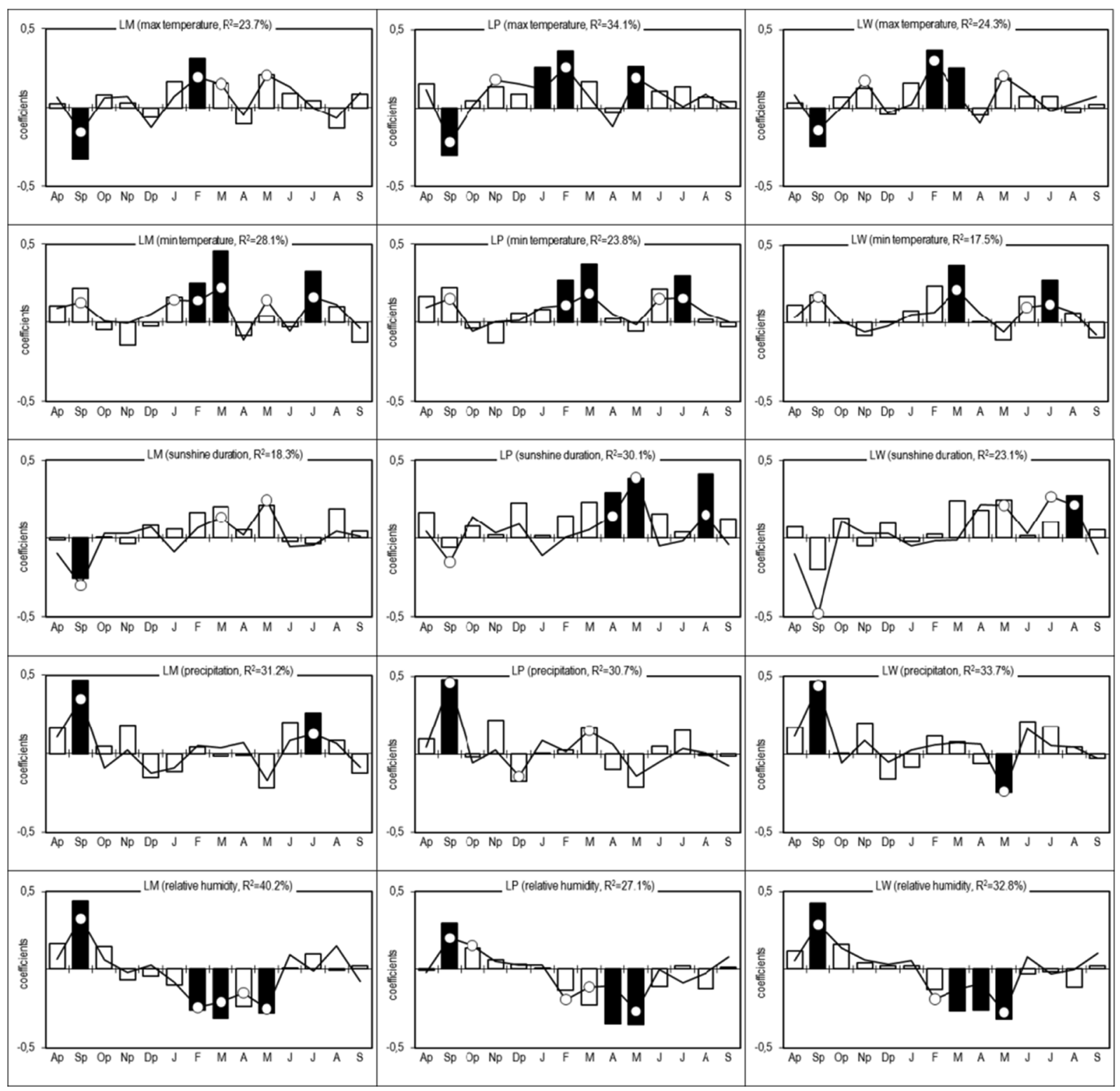

Fig. 8 Correlation (bars) and response function (line) coefficients between the site residual chronologies and the monthly maximum and minimum temperatures, total precipitation, sunshine duration, and relative humidity for all months from the previous August

type. It is known that the site type has an influence on the incremental rhythm of the trees (Friedrichs et al. 2009; Cedro and Lamentowicz 2011; Dauskane et al. 2011; Wilczyński and Kulej 2013). This most probably resulted in the incremental index series of the pines from the position of the LM was different. We also noted a significantly lower value of $\delta^{13} \mathrm{C}$ (Fig. 9) for the LM population. The isotopic composition of pine needles in this investigated site was similar in 2012 and 2013,
(Ap) to the current September (S) from 1951 to 2012. Significant values (at the $95 \%$ confidence limit) - black bars and white dots, $R^{2}$ - the coefficient of multiple determination

whereas the $\delta^{13} \mathrm{C}$ values in samples collected in 2013 were lower than in the samples collected in 2012 in LW and LP population. The decrease of $\delta^{13} \mathrm{C}$ corresponds to the increase of $\mathrm{CO}_{2}$ emission to the atmosphere (Pazdur et al. 2007; McCarroll et al. 2009; Keeling et al. 2010; Sensuła et al. 2011; Sensuła and Pazdur 2013a, b).

Human alterations of the carbon, nitrogen, and sulfur cycle have influenced the dynamics, biodiversity, and functioning of many ecosystems and ecological 


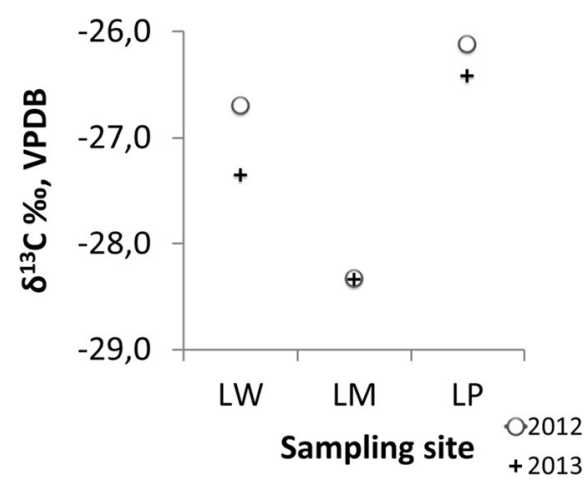

Fig. 9 Stable carbon isotope fractionation in pine needles, collected in 2012 and 2013 from investigated sites

processes. Abrupt changes in environmental conditions, such as increase in air pollution, can be responsible for the occurrence of abrupt growth reductions or missing rings and also for differences in isotopic fractionation (Schweingruber 1986, 1996). A few dendrochronological analysis in association with the isotopic analysis has shown that the long-term modification of the TRW and also carbon isotopic values are indeed modulated by environmental conditions; these conditions could be the following: climate, tree diseases, land use or air quality, as trees absorb natural and anthropogenic compounds (O'Leary 1981; Leavitt and Long 1982; Guerrieri et al. 2009). The analysis of the influence of local air pollution emission on tree rings confirmed the regional (national) negative effect of the increase of $\mathrm{CO}_{2}$ emissions from fossil fuel combustion the negative effect of increase of the local air pollution emissions $\left(\mathrm{CO}, \mathrm{SO}_{2}, \mathrm{NO}_{\mathrm{x}}\right.$, dusts $)$ and also the local negative effect of the distribution of air pollution such as NOx, SOx, and dusts from sources near the investigated site - the Combined Heat and Power Plant in Łaziska. The signal strength is variable and depends on the distance from the source. The reduction of emission of gaseous and dusts emission is also recorded in the TRW. Tree population analyses under these studies were characterized by the varying $r_{b t}$ value. The highest $r_{b t}$ is noted for the $L M$ population, characterized by the lowest damage (the level of reduction and the number of trees with reductions). On the other hand, the LP population has the lowest $r_{b t}$, this population was characterized by the greatest damage (level of reductions and the number of trees with reductions) (see Table 3). The EPS values of each series significantly exceeded the value of 0.85 ; therefore, each of the chronologies are characterized by high representativeness. Different climatic factors occurring in the previous and current year had an impact on the variability of the radial growth of the investigated pines. The results of the analyses of climate-growth relationships for 3 populations were similar. This impact was determined by the correlation and response functions, indicating the significance of both types of coefficients (correlation and multiple regression coefficients). It is difficult to clearly identify to which one of the climatic factors the pines from all sites show a similar sensitivity toward, and toward which ones they show a different sensitivity. High values of the
Fig. 10 Effect of variation of $\mathrm{CO}_{2}$ emissions from fossil fuel combustion in Poland on the dynamics of pine radial growth (locally weighted scatter plot smoothing)

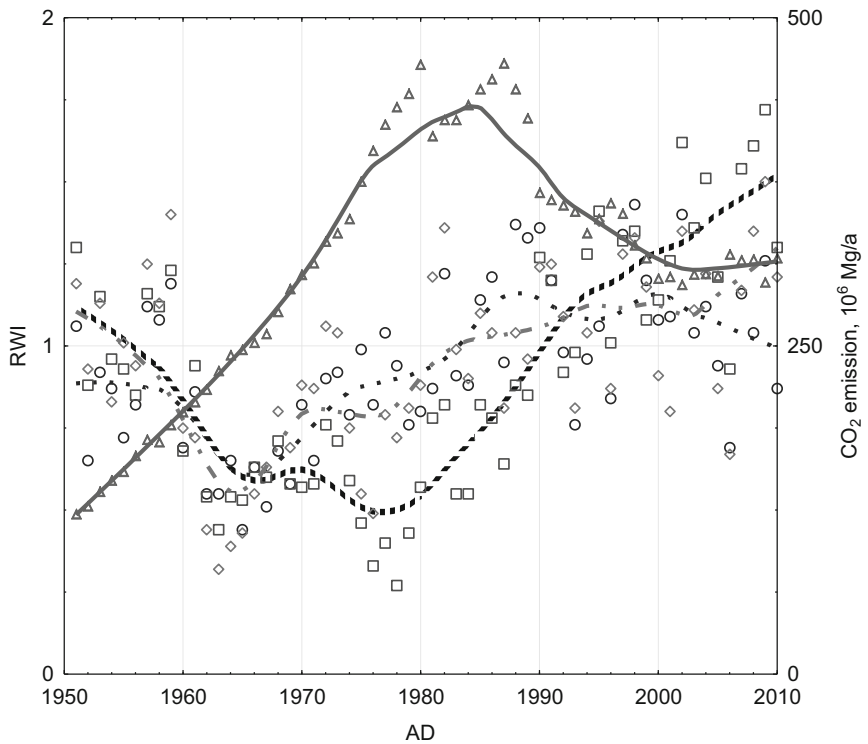

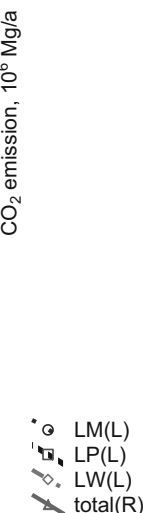


Fig. 11 Effect of the decrease of local air pollution emissions $(\mathrm{CO}$, $\mathrm{SO}_{2}, \mathrm{NOx}$, dusts) in the Silesian Province on the dynamics of pine radial growth (locally weighted scatter plot smoothing)

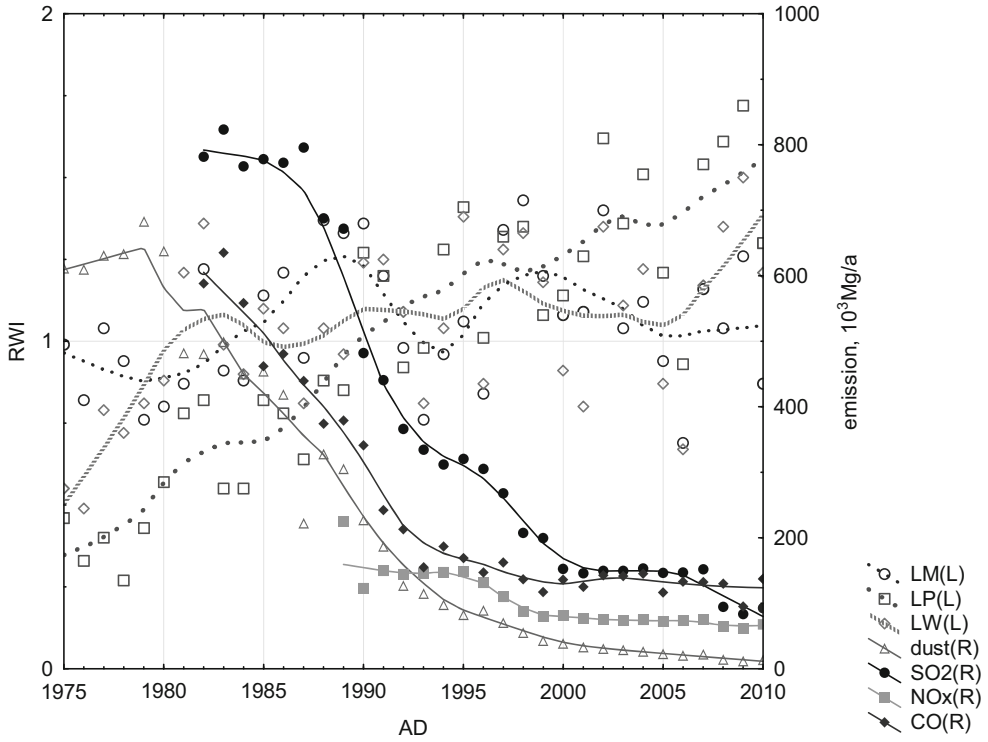

determination coefficients indicate a high sensitivity of the pines on the climatic factor, despite the fact that they were exposed to the pressure of industrial pollution. The analysis of variance is often helpful in this type of assessment (analysis) (Carrer and Urbinati 2004, 2006; Yu et al. 2008; Wu et al. 2013). It also applies principal component analysis by identifying the principal separated individual integral components (Wilczyński and Kulej 2013). The correlation and response function analysis performed for PC1 and PC2 help to identify climatic factors described by the two main components. The impact of weather conditions of the previous year on the growth of the current year is evident (Vaganov 1990; Richter et al. 1991; Lindholm et al. 1996; Spurk 1997;Wilczyński and Skrzyszewski 2002; Helama et al. 2013; Juknys et al. 2014). Our results indicate that if there was significant precipitation in the previous year and the weather conditions were cloudy, humid, and cool, but not cold in September, these conditions were favorable to the radial growth increase in the following year. This is due to the fact that the autumn weather conditions affect the tying buds, which are reflected in the growth of pines in the following year. The amount of generated buds is determined by the abundance of
Fig. 12 Effect of the decrease of local air pollution emissions (CO, $\mathrm{SO}_{2}, \mathrm{NOx}$, dusts) in the Combined Heat and Power Plant in Łaziska on the dynamics of pine radial growth (locally weighted scatter plot smoothing)

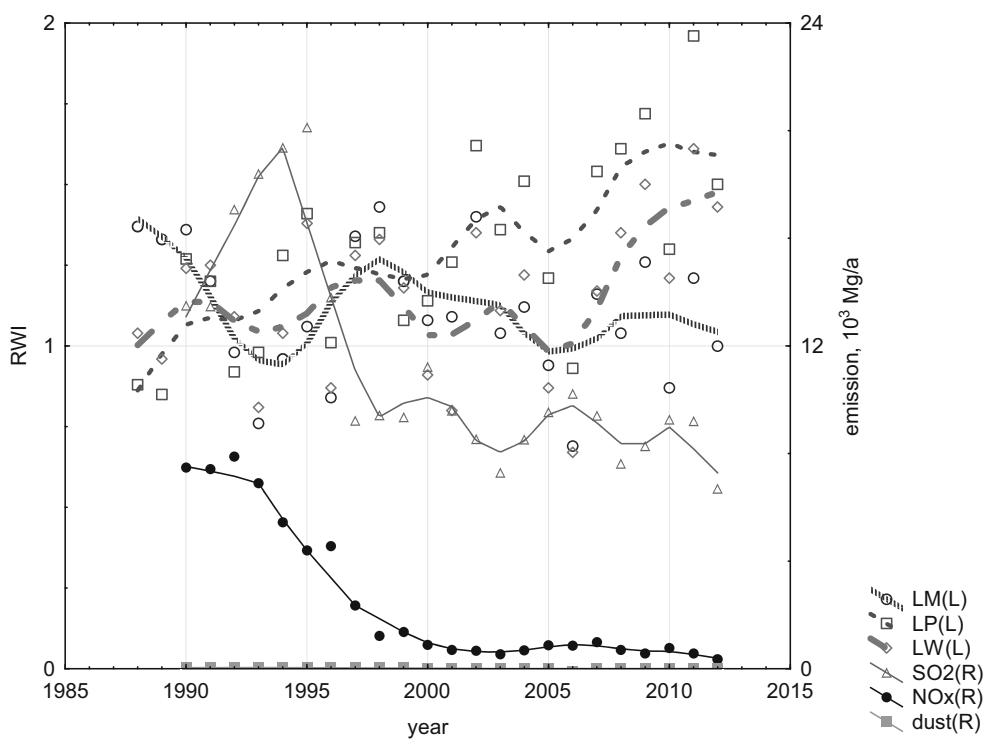


Table 3 The size and extent of the growth reductions: duration of reduction, percentage of trees with reduction, level of reduction, and degree of reduction

\begin{tabular}{lllll}
\hline Lab code & Duration of reduction & Percentage of trees with reductions & Reduction level [\%] & Degree of reduction \\
\hline LW & $1960-1990$ & 70 & 60 & Strong \\
LM & $1961-1980$ & 67 & 36 & Moderate \\
LP & $1962-1989$ & 75 & 65 & Strong \\
\hline
\end{tabular}

flowering in the next year. (La Bastide and Van Vredenburch 1970; Fober 1976; Hejnowicz 1982). Profuse flowering in turn has a negative impact on the tree radial growth (Eis et al. 1965; Chałupka et al. 1976). High temperatures and low humidity in autumn have a positive effect on the flowering of female flowers in the subsequent year. This is evidenced by the results of several studies (Chirov 1964; Andersson 1965; Fober 1976). In turn, cloudy, wet weather with plenty of rain in autumn adversely affect the creation of the buds of flowers (buds) female, preferably donuts and vegetative organs (needles and shoots) (Hejnowicz 1982). These conclusions are supported by the results of our research. Warm and short winters with low humidity positively affect the pines' growth condition, in effect, the physiological processes that led to the earlier cambium divisions in the trees. A similar effect is obtained in the conditions of a dry, sunny, and warm spring. High temperatures in early spring result in the first division in the pine cambium occurring in April (Schober 1951; Ermich 1959). Many researchers reported a positive impact of high temperatures in late winter on the radial growth of the pines (Richter et al. 1991; Spurk 1997; Wilczyński and Skrzyszewski 2002; Juknys et al. 2014). It should be mentioned that in our studies, we found out positive impact of low humidity and of sunshine in the

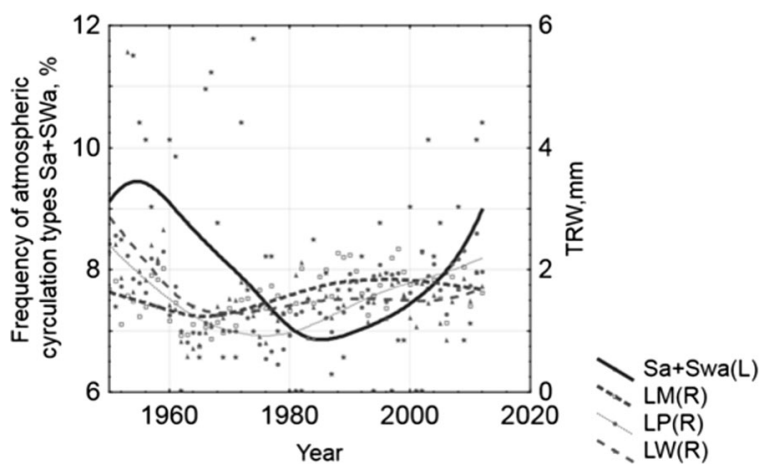

Fig. 13 The influence of Sa and SWa circulation on the tree ring width in the 1951-2012 period (weighted least squares plot smoothing) end of the winter and during spring, on the growth of the pines. Such conditions favor the activation of the cambium and enhance the transpiration of trees, and in effect the increasing of the cambium division. Spurk (1997) points to the positive effects of high humidity on the growth of Scots pine. The relatively high values of determination coefficients, which describe the impact of rain on the growth of the pines, indicate the important role of rainfall in September of the previous year. Low rainfall in May of the current year, which is related to the known positive effects of sunshine on the trees and the low humidity in this month, was also essential for the growth of pines. Abundant rainfall in July of current year had a positive impact on the wood cell formation. This weather condition is conducive to the intense divisions of vascular cambium. Low rainfall during the summer is often a limiting factor for growth pine (Lindholm et al. 1996, 1997; Irvine et al. 1998; Cinnirella et al. 2002; Wilczyński and Skrzyszewski 2002; Tuovinen 2005; Pilcher and Oberhuber 2007; Piovesan et al. 2008; Gruber et al. 2010). It also happens that excess rainfall harms trees, mainly in humid positions (Helama et al. 2013). A shortage of water in the soil when the tree is simultaneously exposed to high temperatures has a particularly negative impact on the tree. The high temperature of the air increases the transpiration which contributes to the disruption of water management in plants. If there is no relationship between TRW and the climatic factors of September of the current year, this means that the radial increment is finished in August. This confirms the results of Henappl (1965) and Schober (1951). Whereas Ermich (1959) shows that large part of the ring is deposited in many species also including pine in September, in the case of favorable weather conditions.

Tree rings of pines from all the investigated sites showed the influence of air pollution visible as growth suppressions. However, the differences between study sites can be observed in terms of the amount of growth reductions and the number of damaged trees. In general, 
the pines which were growing near the Combined Heat and Power Plant (CHP) plant in Łaziska produced suppressed annual rings from 1960 to 1990 (Table 3). The existence of the distinct growth reductions in the period from 1960 to 1990 can be confirmed by the results of earlier studies from other parts of the Silesian Upland (e.g., Danek 2007; Malik et al. 2012). As at every research conducted within the major industrial regions, results show not only the record of pollution of a local type, but a record of pollution transferred from the industry located in the entire Upper Silesian Industrial District is also highly probable. Such a situation was described by Danek (2007). Comparison of frequency of Sa and SWa circulation (Niedźwiedź 2013, Fig. 3c) with the TRW shows that there is an inverse relationship between them (Fig. 13). During the period of growth reductions, the higher frequency of this type of circulation can be noticed. This relationship is not linear, the influence of the amount of pollution in the subsequent years is substantial. However, in the absence of pollution measurement data, this additional data may be useful in order to confirm that increased air pollution resulted in growth suppressions in the 1960s, 1970s, and 1980s.

\section{Conclusions}

Dynamics of Scots pine (P.sylvestris L.) growing in the near-source region of the Combined Heat and Power Plant Łaziska is the response of trees to various climatic and anthropogenic environmental factors. Pines series of 3 positions indicate that they have a similar sensitivity to most climatic elements of the previous and present year, but there are also different rhythms between the studied population incremental pines. The cause of the diversity may be, for example, the results of a different type of habitat (site type) and industrial pollution. Our results indicate the conditions of year previous to the formation of a new tree ring in the following year that favor the activation of cambium and increase the radial growth of pine, enhance the transpiration of trees, such as (1) abundant precipitation in September of previous year; (2) cloudy, humid, and cool, but not cold autumn; (3) warm and short winter with low humidity. Similarly, effects are provided by the condition of a dry, sunny, and warm spring, or low humidity and lots sunshine at the end of the winter and during spring. Low rainfall in May of the current year, which is related to the known positive effects of sunshine on the trees and the low humidity in this month were also essential for the growth of the pines. Abundant rainfall in July of current year had a positive impact on the wood cell formation. The similarity of the short-term incremental rhythm pines growing in different habitats is a fact, and all the above factors also impacted this. It should be noted that in addition to the common incremental features were also different characteristics of the studied incremental pines populations. It turned out that LM pine population differed from the others only in minimal sensitivity to the temperature in February and in late spring and summer. Thus, habitat conditions associated with fertility positions are modeled on the above relationships. We have also noted differences in carbon stable isotope fractionation, which were similar for the LP and LW population, but different in the LM pine population. The dendroecological analysis showed the influence of air pollution on dynamics of radial pine growth as growth suppressions. In general, the pines which grew near the Combined Heat and Power (CHP) Plant in Laziska produced suppressed annual rings from 1960 to 1990 . The obtained results show that the pine tree ring and needles can be an archive not only of local type pollution records, but also they can be an archive of pollution transferred from the industry located in entire province or country. The multiannual series of the frequency of Sa and SWa circulation compared with tree ring index show that there is an inverse relationship between them. This relationship is not linear. The emissions of $\mathrm{SO}_{2}$, $\mathrm{NO}_{\mathrm{x}}, \mathrm{CO}_{2}$, and dusts and other pollution lead to serious disturbance in tree metabolism. In effect, pines growing in industrial regions formed reduced rings. Strong growth declines for all of the sites were noted from the 1960 s till late 1980 s. Since the 1990 s, when proecological strategy was developed in the factory, the emission of pollutants reduction whereas the level of energy production was similar as before the 1990s. This reduction of pollution is recorded in the increase of the TRW. Scots pine populations, investigated under this study, have grown for many years under the pressure of industrial pollution. This influence was reflected mainly in the long-term decline in radial growth. Despite this, the trees are preserved to a large extent, sensitive to the natural climatic factors. This sensitivity of pines can be significant in the reconstruction of the climate in the past so as to better understand the future. The analyses of tree ring $\delta^{13} \mathrm{C}$ variations are promising tools for investigating the carbon deposition to forests. 
Moreover, regional analyses of needles $\delta^{13} \mathrm{C}$ variations could enable the mapping of the impact of carbon deposition on forest ecosystems and in assessing the input of pollutants into plant communities. Such information is strongly needed worldwide.

Acknowledgments The authors wish to express their gratitude to everyone who contributed to making these investigations possible. This project was a part of BIOPOL project entitled: "Trees as bioindicators of industrial air pollution during implementation of the pro-environmental policy in the Silesia region." This project was funded by the National Science Centre allocated on the basis of decision number DEC-2011/03/D/ST10/05251. The research was also a part of IZOPED (BKM/507/2013) and IZOPED 2 (BKM/509/2014) projects founded by the Ministry of Science and Higher Education. The authors also wish to express their gratitude to English native speakers.

Open Access This article is distributed under the terms of the Creative Commons Attribution 4.0 International License (http:// creativecommons.org/licenses/by/4.0/), which permits unrestricted use, distribution, and reproduction in any medium, provided you give appropriate credit to the original author(s) and the source, provide a link to the Creative Commons license, and indicate if changes were made.

\section{References}

Absalon, D., \& Ślesak, B. (2010). The effects of changes in cadmium and lead air pollution on cancer incidence in children. Science of The Total Environment, 408(20), 4420-8. 09.

Absalon, D., \& Ślesak, B. (2012). Air temperature increase and quality of life in an anthropogenically transformed environment: A case study. Polish Journal of Environmental Studies, 21(2), 235-239.

Andersson, E. (1965). Cone and seed studies in Norway spruce (Picea abies (L.) Karst). Study Forest Suec. 23.

Biondi, F., \& Waikul, K. (2004). DENDROCLIM2002: A C++ program for statistical calibration of climate signals in treering chronologies. Computational Geosciences, 30, 303311.

Breymeyer, A. (1998). Transect Studies on Pine Forests Along Parallel $52^{\circ}$ North, $12-32^{\circ}$ East and Along a Pollution Gradient in Poland: General Assumptions, USDA Forest Service Gen.Tech.Rep. PSW-GTR-166.

Carrer, M., \& Urbinati, C. (2004). Age-dependent tree-ring growth response to climate in Larix decidua and Pinus cembra. Ecology, 85, 730-740.

Briffa, K. \& Jones, P. (1992). Basic Chronology Statistics and Assessment. In: Cook ER, Kairiukstis LA. (eds.) Methods of Dendrochronolgy. Springer-Science and Business Media B. V., 137-152.

Carrer, M., \& Urbinati, C. (2006). Long-term change in the sensitivity of tree-ring growth to climate forcing in Larix decidua. New Phytologist, 170, 861-872.
Cedro, A., \& Lamentowicz, M. (2011). Contrasting responses to environmental changes by pine (Pinus sylvestris L.) growing on peat and mineral soil: An example from a Polish Baltic bog. Dendrochronologia, 29, 211-217.

Chałupka, W., Giertych, M., \& Królikowski, Z. (1976). The effect of cone crops on growth in Scot pine on tree diameter increment. Arbor. Kórnickie, 21, 361-366.

Chirov, A. A. (1964). O meteorologičeskom metode prognoza urožaja semjan sosny. Lesn. Choz., 17(9), 47-49.

Cinnirella, S., Magnani, F., Saracino, A., \& Borghetti, M. (2002). Response of a mature Pinus laricio plantation to a three-year restriction of water supply: structural and functional acclimation to drought. Tree Physiology, 22, 21-30.

Cook, E.,\& Innes, J. (1989). Tree-ring analysis as aid evaluating the effects of air pollution on the tree growth. Biologic Markers of Air Pollution Stress and Damage in Forest. The National Academy of Science, 157-168.

Cook, E. R., \& Holmes, R. L. (1999). Program ARSTAN User's Manual. Tucson, AZ: Laboratory of Tree-Ring Research, University of Arizona.

Danek, M. (2007). The influence of industry on Scots pine stands in the south-eastern part of the Silesia-Krakow Upland (Poland) on the basis of dendrochronological analysis. Water, Air and Soil Pollution, 185, 265-277.

Dauskane, I., Brumelis, G., \& Elferts, D. (2011). Effects of climate and extreme radial growth of Scots pine growing on bogs in Latvia. Estonian Journal of Ecology, 60(3), 236-248.

De Vries, W., Reinds, G. J., Klap, J. M., Van Leeuwen, E. P., \& Erisman, J. W. (2000). Effects of environmental stress on forest crown condition in Europe. Part I: hypotheses and approach to the study. Water. Air and Soil Pollution, 119, 317-333.

Eis, S., Garman, H., \& Bell, L. H. (1965). Relation between cone production and diameter increment of Douglas fir (Pseudotsuga menziesii (Mirb.) Franco, Grand fir (Abies grandis (Dougl.) Lindl.) and Western white pine (Pinus monticola Dougl.). Canadian Journal of Botany, 43, 1553-1559.

Elling, W., Dittmar, C., Pfaffelmoser, K., \& Rotzer, T. (2009). Dendroecological assessment of the complex causes of decline and recovery of the growth of silver fir (Abies alba Mill.) in Southern Germany. Forest Ecology and Management, 25(4), 1175-1187.

Ermich, K. (1959). Badania nad sezonowym przebiegiem przyrostu grubości pnia u Pinus silvestris L. i Quercus robur L. (Studies on the seasonal course of the radial increment of Pinus silvestris L. and Quercus robur L). Acta Society of Botany Poland, 28, 15-63 (in Polish).

Fober, H. (1976). Relation between climatic factors and Scots pine (Pinus sylvestris) cone crops in Poland. Arbor Kórnickie, 21, 367-374.

Friedrichs, D. A., Neuwirth, B., Winiger, M., \& Löffler, J. (2009). Methodologically induced differences in oak site classifications in a homogeneous tree-ring network. Dendrochronologia, 27, $21-30$

Fritts, H. C. (1976). Tree Rings and Climate. London: Acad Press. Fritts, H. C., Blasing, T. J., Hayden, B. P., \& Kutzbach, J. E. (1971). Multivariate techniques for specifying tree-growth and climate relationships and for reconstructing anomalies in paleoclimate. Journal of Applied Meteorology, 10(5), 845-864.

Gruber, A., Strobi, S., Veit, B., \& Oberhuber, W. (2010). Impact of drought on the temporal dynamics of wood formation in Pinus sylvestris. Tree Physiology, 30(4), 490-501. 
Guerrieri, M. R., Siegwolf, R. T. W., Saurer, M., Jaggi, M., Cherubini, P., Ripullone, F., \& Borghetti, M. (2009). Impact of different nitrogen emission sources on tree physiology as assessed by a triple stable isotope approach. Atmospheric Environment, 43, 410-418.

Hejnowicz, A. (1982). Budowa i rozwój wegetatywnych paków sosny zwyczajnej Pinus sylvestris L. (Construction and development of vegetative buds of Scots pine (Pinus sylvestris L. Kórnik: Instytut Dendrologii PAN.

Helama, S., Mielikäinen, K., Timonen, M., Herva, H., Tuomenvirta, H., \& Veneäläinen, A. (2013). Regional climatic signals in Scots pine growth with insights into snow and soil associations. Dendrobiology, 70, 27-34.

Heller, F., Strzyszcz, Z., Magiera, T. (1998), Magnetic record of industrial pollution in forest soils of Upper Silesia, Poland, Journal of Geophysical Research. Vol.103(B8) 17; 767-17, 774.

Henappl G. (1965). Über die Stärkenänderung der peripheren Stammzone von Waldbäumen im Jahresverlauf. Diss., Univ. Freiburg.

Holmes, R. L., \& Lough, J. M. (1999). RESPO - Response and correlation function. Tucson: Laboratory of Tree-Ring Research, Univ. of Arizona.

Holmes, R. L. (1983). Computer-assisted quality control in treering dating and measurement. Tree-Ring Bulletin, 43, 69-78.

Irvine, J., Perks, M. P., Magnani, F., \& Grace, J. (1998). The response of Pinus sylvestris to drought: stomatal control of transpiration and hydraulic conductance. Tree Physiology, 18, 393-402.

Juknys, R., Augustaitis, A., Vencloviene, J., Kliučius, A., Vitas, A., Bartkevičius, \& Jurkonis, N. (2014). Dynamic response of tree growth to changing environmental pollution. European Journal of Forest Research, 133, 713-724.

Keeling, R.F., Piper, S.C., Bollenbacher, A.F., \& Walker, S.J. (2010). Monthly atmospheric ${ }^{13} \mathrm{C}^{12} \mathrm{C}$ isotopic ratios for 11 SIO stations. In Trends: A Compendium of Data on Global Change. Carbon Dioxide Information Analysis Center, Oak Ridge National Laboratory, U.S. Department of Energy, Oak Ridge, Tenn., U.S.A.

Kondracki, J. (2001). Geography of Poland. Physical-geographic mesoregions, Warszawa PWN, 185-186 (In Polish).

La Bastide, J.G., \& Van Vredenburch, C.L.H. (1970). The influence of weather conditions on the seed production of some forest trees in the Netherlands. Stichting Bosbouwproefstation 'De Dorschkamp', Waegeningen, Mededeling 102.

Lazar, J. (1962). The soils of Katowice province. PWRiL, Warszawa: ŚIN w Katowicach (In Polish).

Leśniok, M. (2011). Changeability of Air Pollution in Katowice Region (Central Europe, Southern Poland), Advanced Air Pollution. Nejadkoorki F (Ed.), ISBN: 978-953-307-511-2, InTech. http://www.intechopen.com/books/advanced-airpollution/changeability-of-air-pollution-in-katowice-regioncentral-europe-southern-poland. Accessed 01 June 2014

Leśniok, M., Małarzewski, Ł., \& Niedźwiedź, T. (2010). Classification of circulation types for Southern Poland with an application to air pollution concentration in Upper Silesia. Physics and Chemistry of the Earth, 35, 516-522.

Levanič, T., \& Slapnik, A. (2006). Dendroekološka analiza rastismreke (Piceaabies(L.) Karst.) v okolici dveh termoelektrarn. Zbornik gozdarstva in lesarstva, 79, 3-18.
Lindholm, M., Meriläinen, J., Timonen, M., Vanninen, P., \& Eronen, M. (1997). Effects of climate on the growth of Scots pine in the Saimaa lake district, south-eastern Finland, in the southern part of the boreal forest belt. Dendrochronologia, 15, 151-168.

Lindholm, M., Timonen, M., \& Meriläinen, J. (1996). Extracting mid-summer temperatures from ring-width chronologies of living pines at the northern forest limit in Fennoscandia. Dendrochronologia, 14, 99-113.

Malik, I., Danek, M., Marchwińska-Wyrwał, E., Danek, T., Wistuba, M., \& Krapiec, M. (2012). Scots pine (Pinus sylvestris L.) growth suppression and adverse effects on human health due to air pollution in the Upper Silesian Industrial District (USID), Southern Poland. Water Air and Soil Pollution, 223, 3345-3364.

Marland, G., Boden, TA., \& Andres, R.J. (2008). Global, Regional, and National Fossil Fuel $\mathrm{CO}_{2}$ Emissions. In Trends: A Compendium of Data on Global Change. Carbon Dioxide Information Analysis Center, Oak Ridge National Laboratory, U.S. Department of Energy, Oak Ridge, Tenn., U.S.A.

Matuszkiewicz, J.M. (2008). Potential natural vegetation of Poland, Map sheet: C3, IGIPZ PAN, Warszawa. http:// www.igipz.pan.pl/tl_files/igipz/ZGiK/opracowania/ roslinnoscpotencjalna/prn_opracowanie.pdf. Accessed 01 October 2014

McCarroll, D., Gagen, M. H., Loader, N. J., Robertson, I., Anchukaitis, K. J., Los, S., Young, G., Jalkanen, R., Kirchhefer, A., \& Waterhouse, J. S. (2009). Correction of tree ring stable carbon isotope chronologies for changes in the carbon dioxide content of the atmosphere. Geochimica et Cosmochimica Acta, 2009(73), 1539-1547.

Niedźwiedź, T. (2013). Calendar of Circulation Types for teritory of Southern Poland - digital dataset. Uniwersytet Śląski, Katedra Klimatologii, Sosnowiec. http://klimat.wnoz.us. edu.pl/\#!/podstrony/kalendarztn Accessed 01 October 2014

Niedźwiedź, T., \& Ustrnul, Z. (1989). Influence of synoptic situations on the occurrence of weather types favorable to concentration or dispersion or air pollution above the Upper Silesia Industrial Region. Wiadomości Insytutu Meteorologii i Gospodarki Wodnej, 12(1-2), 31-39 (In Polish).

O'Leary, M. (1981). Carbon isotope fractionation in plants. Phytochemistry, 20, 553-567.

Leavitt, S., \& Long, A. (1982). Stable carbon isotopes as a potential supplemental tool in dendrochronology. Tree Ring Bulletin, 42, 49-56.

Pazdur, A., Kuc, T., Pawelczyk, S., Piotrowska, N., Sensula, B., \& Rozanski, K. (2013). Carbon isotope composition of atmospheric carbon dioxide in Southern Poland: imprint of anthropogenic $\mathrm{CO} 2$ emissions in regional biosphere. Radiocarbon, 55, 848-864.

Pazdur, A., Nakamura, T., Pawelczyk, S., Pawlyta, J., Piotrowska, N., Rakowski, A. Z., Sensula, B., \& Szczepanek, M. (2007). Carbon isotopes in tree rings: Climate and Human activities in the last 400 years. Radiocarbon, 49, 775-778.

Pilcher, P., \& Oberhuber, W. (2007). Radial growth response of coniferous forest trees in an inner Alpine environment to heat wave in 2003. Forest Ecology and Management, 242, 688699.

Piovesan, G., Biondi, F., Di Filippo, A., Alessandrini, A., \& Maugeri, M. (2008). Drought-driven growth reduction in 
old beech (Fagus silvatica) forests of the central Apennines, Italy. Global Change Biology, 14, 1265-1281.

Richter, K., Eckstein, D., \& Holmes, R. L. (1991). The dendrochronological signal of pine trees (Pinus spp.) in Spain. TreeRing Bulletin, 51, 1-13.

Rinn, F. (2010). TSAP - reference manual. Heidelberg: Frank Rinn.

Schober, R. (1951). Zum jahreszeitlischen Ablauf des sekundären Dickenwachstums. Allg. Forst- und Jagdzeitg., 122, 81-96.

Schweingruber, F. H. (1986). Abrupt growth changes in conifers. IAWA Bulletin, 7(4), 277-283.

Schweingruber, F.H., (1996). Tree Rings and Environment. Dendroecology. Swiss Federal Institute for Forest, Snow and Landscape Research, and Paul Haupt Verlag. 609 pp.

Sensuła, B., Pazdur, A., \& Marais, M. F. (2011). First application of mass spectrometry and gas chromatography in $\alpha$-cellulose hydrolysates investigation: the influence of climate changes on glucose molecules in pine tree-rings. Rapid Communications In Mass Spectrometry, 25, 489-494.

Sensuła, B., \& Pazdur, A. (2013a). Influence of climate change on carbon and oxygen isotope fractionation factors between glucose and $\alpha$-cellulose of pine wood. Geochronometria, 40(2), 145-152.

Sensuła, B., \& Pazdur, A. (2013b). Stable carbon isotopes of glucose received from pine tree-rings as bioindicators of local industrial emission of $\mathrm{CO}_{2}$ in Niepołomice Forest (19502000). Isotopes in Environmental and Health Studies, 49(4), 532-541.

Speer, J. H. (2010). Fundamentals of Tree-Ring Research. Tucson: The University of Arizona Press.

Spurk, M. (1997). Dendroklimatologische Untersuchengen an Kiefern (Pinus sylvestris L.) der planar-kollinen Stufe in Deutschland. Dendrochronologia, 15, 51-72.

Szychowska-Krapiec, E., \& Wiśniowski, E. (1996). Tree-ring analysis of Pinus silvestris as a method to assess the industrial pollution impact on the example of "Police" chemical factory (NW Poland). Zastosowanie analizy przyrostów rocznych sosny zwyczajnej (Pinus silvestris) do oceny wpływu zanieczyszczeń przemysłowych na przykładzie Zakładów Chemicznych „Police” (woj. szczecińskie) (inPolish). Kwartalnik AGH Geologia, 22(3), 281-299.
Szypuła, B. (2014). Quantitative changes of anthropogenic relief over the last 100 years in the Silesian Upland (south Poland). Zeitschrift für Geomorphologie, 58(2), 175-183.

Tuovinen, M. (2005). Response of tree-ring width and density of Pinus sylvestris to climate beyond the continuous northern forest line in Finland. Dendrochronologia, 22, 83-91.

Vaganov, E. A. (1990). The tracheidogram method in tree-ring analysis and its application. In E. R. Cook \& L. A. Kairiukstis (Eds.), Methods of Dendrochronology (pp. 63-76). Dodrecht, Boston, London: Kluwer Academic Publ.

Vitousek, P. M., Aber, J. D., Howarth, R. W., Likens, G. E., Matson, P. A., Schindler, D. W., Schlesinger, W. H., \& Tilman, D. G. (1997). Human Alteration Of The Global Nitrogen Cycle: Sources And Consequences. Ecological Applications, 7, 737-750. doi:10.1890/1051-0761(1997) 007[0737:Haotgn]2.0.Co;2.

Wigley, T. M. L., Briffa, K. R., \& Jones, P. D. (1984). On the Average Value of Correlated Time Series, with Applications in Dendroclimatology and Hydrometeorology. Journal of Applied Meteorology and Climatology, 23, 201-213.

Wilczyński, S., \& Kulej, M. (2013). The influence of climate on the radial increment of larches of different provenances on the basis of the experiment in the Carpathian Mountains in Southern Poland. European Journal of Forest Research, 132, 919-929.

Wilczyński, S., \& Skrzyszewski, J. (2002). The climatic signal in tree-rings of Scots Pine (Pinus sylvestris L.) from foot-hills of the Sudetic Mountains (southern Poland). Forstwis Cbl, 121, 15-24.

Wilczyński, S. (2006). The variation of tree-ring widths of Scots pine (Pinus sylvestris L.) affected by air pollution. European Journal of Forest Research, 125, 213-219.

Wu, G., Xu, G., Chen, T., Liu, X., Zhang, Y., An, W., Wang, W., Fang, Z., \& Yu, S. (2013). Age-dependent tree-ring growth responses of Schrenk spruce (Picea schrenkiana) to climateA case study in the Tianshan Mountain, China. Dendrochronologia, 31, 318-326.

Yu, G., Liu, Y., \& Wang, X. (2008). Age-dependent tree-ring growth responses to climate in Qilian juniper (Sabina przewalskii Kom.). Trees. doi:10.1007/s00468-007-0170-y. 